\title{
TRANSFORMASI PENDIDIKAN PROFETIK SEBEGAI PERWUJUDAN PILAR PENDIDIKAN NASIONAL DI MADRASAH
}

\author{
Yayuk Kusumawati \\ Institut Agama Islam (IAI) Muhammadiyah Bima \\ Email: yayukalkhansa@gmail.com
}

\begin{abstract}
Abstrak
Dalam artikel ini akan membahas secara teoritis dan praktis tentang transformasi pendidikan profetik sebagai perwujudan pilar pendidikan nasional di madrasah. Transformasi pendidikan profetik harus mengacu pada pendidikan yang berorientasi pada pananaman nilai-nilai kebangsasaan, dengan mempertimbangkan warisan pendidikan masa lalu, masa kini serta kemampuannya mengantisipasi tantangan perkembangan zaman. Sekarang ini bangsa dan pemerintah Indonesia semakin menyadari dan menyesali, bahwa bahwa aspek pilar pendidikan nasional telah terabaikan sehingga kalah bersaing dengan nagera-negara lain.. Jenis penelitian yang digunakan dalam penulisan ini adalah penelitan kepustakaan (Library Research), yaitu serangkaian penelitian yang berkenaan dengan metode pengumpulan data pustaka, atau penelitian yang digali melalui beragam informasi kepustakaan seperti buku, ensiklopedi, jurnal ilmiah, koran, majalah, penelitian terdahulu dan dokumen. Adapun pembehasan dalam tulisan ini, Penerapan pendidikan profetik di madrasah bertujuan untuk mengarahkan peserta didik untuk berpartisipasi secara aktif dalam mengimplementasikan nilai-nilai perjuangan Rasulullah SAW yakni humanisasi, liberasi dan transendensi. Selain itu, Dalam konteks pendidikan secara formal pendidikan profetik dapat diterapkan untuk mewujudkan pilar pendidikan nasional melalui proses pembelajaran yang dilaksanakan di madrasah. Belajar menggunakan pendekatan pilar pendidikan, murid akan termotivasi dalam mengembangkan ilmu pengetahuan, pengalaman, dan keterampilan berpikir yang logis dan sistematis, sehingga suasana proses belajar mengajar menjadi kondusif, komunikatif dan tercipta hubungan harmonis antara guru dan peserta didik.
\end{abstract}

Kata Kunci: Transformasi, Profetik, Pilar Pendidikan

\section{PENDAHULUAN}

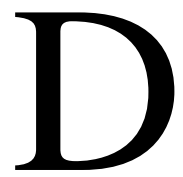

ewasana ini kita sedang menghadapi gelombang kehidupan politik berbasis bebas nilai, sehingga amat sulit bagi instansi dan pelaku pendidikan untuk beradaptasi dengan realitas yang sedang terjadi. Iklim perpolitikan yang kurang kondusif, bahkan cenderung mengarah pada kebebasan yang kurang terkendali dapat 
menimbulkan berbagai persoalan dalam berbagai bidang kehidupan termasuk pendidikan. Mulyasa menyebutkan, bahwa dalam tatanan akar rumput hal tersebut telah menimbulkan berbagai gejala dan masalah sosial, seperti premanisme, perkelahian warga, pencurian, pelecehan seksual, geng motor dan lain-lain. Bahkan tidak sedikit kegiatan yang mengancam keutuhan Negara Kesatuan Republik Indonesia (Mulyasa, 2013).

Paradigma pendidikan bebas nilai harus digeser menjadi pendidikan berbasis nilai, hal ini untuk mempercepat proses penanaman nilai-nilai pendidikan profetik. Misi pendidikan profetik tidak terlepas dari misi utama Nabi Muhammad SAW untuk memperbaiki karakter dan perilaku umat. Perbaikan karakter dan perilaku merupakan bagian sangat penting untuk membangun kualitas hidup dan peradaban manusia (Azyumardi Azra, 1999). Pendidikan profetik sejatinya merupakan proses untuk memanusiakan manusia, dalam konteks ini ada dua agenda penting yakni proses pemanusiaan dan proses kemanusiaan (Sudarwan Danim, 2006). Oleh karena itu, pembentukan karakter merupakan bagian dari pendidikan profetik yang diimplementasikan melalui institusi pendidikan di sekolah. Sekolah bertanggung jawab bukan hanya dalam mencetak peserta didik yang unggul dalam ilmu pengetahuan dan teknologi, tetapi juga dalam jati diri dan kepribadian (Azyumardi Azra, 2006).

Pembinaan kehidupan moral manusia dan penghayatan keislaman dalam kehidupan seseorang sebenarnya bukan sekedar mempercayai seperangkat keyakinan dan melaksanakan tatacara upacara keagamaan saja, tetapi merupakan usaha yang terus menerus untuk menyempurnakan diri pribadi dalam hubungan vertical kepada Allah SWT dan horizontal terhadap sesama manusia sehingga mewujudkan keselarasan, keserasian, keseimbangan hidup menurut fitrah kejadiannya sebagai makhluk individu, makhluk sosial serta makhluk yang berketuhanan yang Maha Esa (Marwan Saridjo, 1996).

Bagi bangsa Indonesia, transformasi pendidikan profetik harus mengacu pada pendidikan yang berorientasi pada pananaman nilai-nilai kebangsasaan, dengan mempertimbangkan warisan pendidikan masa 
lalu, masa kini serta kemampuannya mengantisipasi tantangan perkembangan zaman (Tim PGRI, 2014). Sekarang ini bangsa dan pemerintah Indonesia semakin menyadari dan menyesali, bahwa bahwa aspek pilar pendidikan nasional telah terabaikan sehingga kalah bersaing dengan nagera-negara lain. Padahal, Indonesia sesungguhnya memiliki modal dan warisan yang jauh lebih kaya dari segi sumber daya alam dan kebudayaan dibanding dengan Negara lain (Komarudin Hidayat, 2014).

Agenda pendidikan, sejatinya adalah agenda pembangunan moral dan budaya bangsa. Sasaran akhir pendidikan adalah peningkatan budaya bangsa, bukan sekedar membekali ilmu pengetahuan dan keterampilan yang kemudian ditandai dengan ijazah. Sekarang ini bangsa dan pemerintah Indonesia semakin menyadari dan menyesali, bahwa aspek dan pilar pendidikan nasional ini terabaikan sehingga kalah bersaing dengan Negara-negara lain. Padahal, Indonesia sesungguhnya memiliki modal dan warisan yang jauh lebih kaya baik dari sumber daya alam dan kebudayaan dibanding Negara lain (Komarudin Hidayat, 2014). Upaya mewujudkan pilar pendidikan nasioanl terus mengahadapi berbagai persoalan yang sangat serius, hal ini ditandai dengan terjadinya beberapa kali perubahan terhadap kurikulum pendidikan kita.

Upaya untuk mencapai tujuan di atas dapat ditempuh melalui pengembangan kemampuan peserta didik dalam praktek pembelajaran yang menyeluruh dan terpadu di Madrasah. Pembelajaran yang baik harus mempunyai tujuan membelajarkan peserta didik untuk memperoleh hasil belajar berupa perpaduan antara aspek kognitif, afektif, dan psikomotor secara seimbang dengan nilai-nilai karakter religius Penerapan pembelajaran di madrasah biasa disebut sebagai suatu upaya untuk memperbaiki kualitas pendidikan, terutama dalam rangka mengimbangi gejala penjejalan isi kurikulum yang sering terjadi dalam proses pembelajaran yang dilaksanakan di madrasah-madrasah.

Dari penjelasan diatas, tulisan ini akan mengupas secara teoritis dan praktis tentang transformasi pendidikan profetik sebagai perwujudan pilar pendidikan nasional di madrasah. Kajian ini sebagai bagian dari proses untuk menciptakan konsep pendidikan yang mengarustumakan kepentingan bangsa dibanding kepentingan lain. Sehingga agenda 
pendidikan yang sejatinya adalah agenda pembangunan moral dan budaya bangsa bisa terwujud.

\section{TINJAUAN TEORITIS}

\section{Pendidikan Profetik}

Urgensi dari pemikiran seorang pemikir Indonesia (kuntowijoyo) layak untuk kita perbincangkan menjadi sebuah alternatif baru dalam menghadapi persoalan pendidikan bangsa Indonesia dengan konsep pendidikan profetik ala kuntowijoyo (M. fahmi, 2005). Kata "profetik" berasal dari bahasa inggris prophetical yang mempunyai makna Kenabian atau sifat yang ada dalam diri seorang nabi (Kuntowijoyo, 2001). Yaitu sifat nabi yang mempunyai ciri sebagai manusia yang ideal secara spiritual-individual, tetapi juga menjadi pelopor perubahan, membimbing masyarakat ke arah perbaikan dan melakukan perjuangan tanpa henti melawan penindasan. Dalam sejarah, Nabi Ibrahim melawan Raja Namrud, Nabi Musa melawan Fir'aun, Nabi Muhammad yang membimbing kaum miskin dan budak belia melawan setiap penindasan dan ketidakadilan, mempunyai tujuan untuk menuju kearah pembebasan (Muhammad Basyam Rusydi Az-Zain, 2007). Menurut Ali Syari'ati dalam Hilmy para nabi tidak hanya mengajarkan dzikir dan do'a tetapi mereka juga datang dengan suatu ideology pembebasan (Ali Shari'ati, 1996).

Nabi (Prophet) yang menjadi acuan dalam pendidikan profetik adalah Nabi Muhammad SAW yang mana sebagai suri tauladan dan sebagai pendidik yang hebat. Nabi Muhammad SAW menyebarkan dan mengajarkan islam di Makkah yang tadinya kondisi mereka menyembah berhala, musyrik, dan sombong, maka dengan usaha dan kegiatan Nabi mengajarkan Islam kepada mereka, lalu tingkah laku mereka berubah menjadi penyembah Allah, menjadi mukmin, muslim dan menghormati orang lain. Mereka telah berkepribadian mukmin sebagaimana yang dicita-citakan Islam. Dengan itu Nabi telah mendidik, membentuk kepribadian yaitu kepribadian muslim dan Nabi Muhammad SAW sekaligus menjadi pendidik yang berhasil. Di dalam kehidupannya nabi SAW selalu memberikan ketauladanan kepada ummatnya. Hal inilah 
yang menjadikan Nabi Muhammad menjadi acuan Profetik atau kenabian dalam hal pendidikan.

Jadi, Pendidikan Profetik adalah proses transfer pengetahuan (knowledge) dan nilai (values) kenabian yang bertujuan untuk membangun akhlak, moral serta mendekatkan diri kepada Tuhan dan alam sekaligus memahaminya untuk membangun komunitas sosial yang ideal (khairul ummah). Serta tercapainya intelektual, emosional, akhlak dan moral peserta didik yang dapat berkembang secara utuh (Syaifullah Godi Ismail, 2012).

Secara definitif, pendidikan profetik dapat dipahami sebagai seperangkat teori yang tidak hanya mendeskripsikan dan mentransformasikan gejala sosial, dan tidak pula hanya mengubah suatu hal demi perubahan, namun lebih dari itu, diharapkan dapat mengarahkan perubahan atas dasar cita-cita etik dan profetik. Kuntowijoyo sendiri memang mengakuinya, terutama dalam sejarahnya Islamisasi Ilmu itu seperti hendak memasukan sesuatu dari luar atau menolak sama sekali ilmu yang ada. Beliau mengatakan: "saya kira keduanya tidak realistik dan akan membuat jiwa kita terbelah antara idealitas dan realitas, terutama bagi mereka yang belajar ilmu social barat. Bagaimana nasib ilmu yang belum di Islamkan? Bagaimana nasib Islam tanpa Ilmu?. Dengan ungkapan seperti ini, Kuntowijoyo tidak bermaksud menolak Islamisasi ilmu, tapi selain membedakan antara ilmu sosial profetik dengan Islamisasi Ilmu itu sendiri, juga bermaksud menghindarkan pandangan yang bersifat dikotomis dalam melihat ilmuilmu Islam dan bukan Islam (Kuntowijoyo, 1991).

Selanjutnya, Kuntowijoyo memasukan kata profetik kedalam penemuannya tentang ilmu-ilmu sosial profetik yang mengandung tiga muatan ilmu-ilmu sosial yaitu humanisme, leberasi, dan transendensi (Kuntowijoyo, 2001). Secara normatif-konseptual, paradigma profetik versi Kuntowijoyo didasarkan pada Surat Ali-Imran ayat 110 yang terjemahannya:

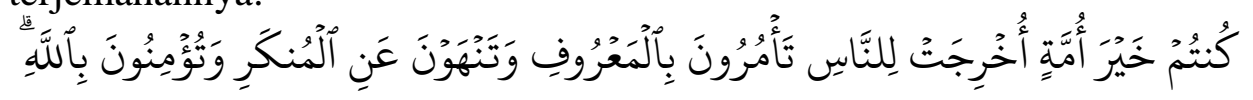


Artinya: Engkau adalah umat terbaik yang diturunkan/dilahirkan ditengah-tengah manusia untuk menyuruh kepada yang ma'ruf dan mencegah kemunkaran dan beriman kepada Allah (Departemen Agama RI, 2009).

Dari ayat diatas menjelaskan dasar ketiga pilar nilai ilmu sosial profetik yang digunakan oleh Kuntowijoyo yaitu; 1) Amar Ma'ruf (humanisasi) mengandung pengertian memanusiakan manusia. 2) Nahi Munkar (liberasi) mengandung pengertian pembebasan. 3)Tu'minuna Bilah (transendensi), dimensi keimanan manusia (Kuntowijoyo, 2007).

\section{Pilar Pendidikan Nasional}

Dalam mewujudkan cita-cita mencerdaskan kehidupan bangsa, serta sejalan dengan visi dan misi pendidikan nasional, Kemendiknas (Restra Kemendiknas 2010-2014) mempunia visi 2025 untuk menghasilkan insan Indonesia Cerdas dan Kompetitif (Insan Kamil/insan paripurna). Insan Indonesia cerdas adalah insan yang cerdas kompetitif, yaitu cerdas spiritual, cerdas emosional, cerdas sosial, cerdas intelektual, dan cerdas kisentetis (Mulyasa, 2013).

Pendidikan nasional berfungsi mengembangkan kemampuan dan membentuk watak serta peradaban bangsa yang bermartabat dalam rangka mencerdaskan kehidupan bangsa. Untuk itu, pendidikan nasional bertujuan untuk mengembangkan potensi peserta didik agar menjadi manusia yang beriman dan bertakwa kepada Tuhan Yang Maha Esa, berakhlak mulia, sehat, berilmu, cakap, kreatif, mandiri, dan menjadi warga Negara yang demokratis serta bertanggung jawab (Undangundang No. 20 Tahun 2003).

Pendidikan adalah aset masa depan dalam membentuk SDM yang berkualitas. Peningkatan SDM perlu ditangani oleh sistem pendidikan yang baik, pengelola yang profesional, tenaga guru yang bermutu, sarana belajar dan anggaran pendidikan yang cukup. Pendidikan memiliki spektrum masa depan yang luas dan seimbang sehingga harapan masyarakat terhadap pendidikan terpenuhi, dan manusia Indonesia seutuhnya dapat diwujudkan. Pendidikan harus dibawa dalam rangka mengoptimalkan kemampuan peserta didik untuk memiliki sifat kreatif, kritis dan tanggap terhadap masalah kehidupan. 
UNESCO sebagai lembaga yang mengurusi masalah pendidikan di bawah naungan PBB dalam Sindhunata, mengemukakan keberhasilan pendidikan diukur dari hasil empat pilar pengalaman belajar (empat buat sendi atau pilar pendidikan dalam rangka pelaksanaan pendidikan untuk masa sekarang dan masa depan) yang diorientasikan pada pencapaian ranah kognitif, afektif, dan psikomotorik, yakni belajar mengetahui (learning to know), belajar berbuat (learning to do), belajar menjadi seseorang (learning to be) dan belajar hidup bersama (learning to live together). Dengan diterapkannya empat pilar pendidikan ini diharapkan para guru mampu mendampingi peserta didiknya agar menjadi manusia yang berkualitas di kemudian hari. Dan untuk menciptakan pembelajaran yang berkualitas yang bermuara pada penciptaan suasana pembelajaran yang aktif, kreatif, efektif, dan menyenangkan. Paradigma tersebut kemudian dikenal dengan istilah PAKEM dan mendapatkan rekomendasi dari UNESCO sebagai satu bentuk pembelajaran efektif, dengan mengacu pada empat pilar pendidikan juga (Mastuhu, 2001).

\section{Learning To Know}

Pilar pertama ini memeliki arti bahwa para peserta didik dianjurkan untuk mencari dan mendapatkan pengetahuan sebanyakbanyaknya, melalui pengalaman-pengalaman. Hal ini akan dapat memicu munculnya sikap kritis dan semangat belajar peserta didik meningkat. Learning to know selalu mengajarkan tentang arti pentingnya sebuah pengetahuan, karena didalam learning to know terdapat learning how to learn, artinya peserta didik belajar untuk memahami apa yang ada di sekitarnya, karena itu adlah proses belajar. Hal ini sesuai pendapat Abu Ahmadi dan Widodo Supriyono, yaitu belajar adalah suatu proses usaha yang dilakukan individu untuk memperoleh suatu perubahan tingkah laku yang baru secara keseluruhan sebagai hasil pengalaman individu itu sendiri dalam interaksi dengan lingkungannya (Abu Ahmadi, 2004).

\section{Learning to do}

Ini memiliki kemiripan dengan aspirasi pragmatic, yaitu belajar dalam hubungannya dengan dunia kerja. Belajar untuk melakukan dengan dunia kerja. Belajar untuk melakukan dengan 
mengacu pada penguasaan keterampilan praktis, bakat untuk bekerja dalam tim, inisiatif, serta kesiapan dalam mengambil resiko. Dengan demikian, pilar ini adalah tentang menempatkan kompetensi dari yang telah dipelajari dalam praktik sehingga mampu bertindak kreatif pada lingkungan kita. Dalam belajar untuk melakukan terkandung juga pembelajaran tentang cara dan metode dalam melakukan sesuatu.

3. Learning to Live Together

Pilar ini menekankan kesadaran tentang pentingnya mengerti keadaan orang lain melalui dialog. Pembelajaran menurut pilar ini adalah upaya untuk mengembangkan empati, respek, dan penghargaan terhadap orang lain. Namun, jika kita ingin memahami orang lain, pertama kita harus tahu diri kita sendiri. Belajar untuk hidup bersama juga terkait dengan mengakui saling ketergantungan diantara kita, tentang tujuan bersama, dan tentang upaya bersama untuk masa depan bersama. Dalam konteks Indonesia, pilar ini sangat penting sehubungan dengan kondisi kita yang plural. Mengelola konflik dengan cara damai hanya mungkin terlaksana secara mendasar dan efektif melalui visi ini.

\section{Learning To Be}

Merupakan dasar bahwa pendidikan harus memberikan kontribusi bagi pengembangan masing-masing individu agar menjadi manusia seutuhnya. Manusia sebagaimana tergambar dalam uraian diatas adalah homo potens yang memerlukan lingkungan untuk tumbuh dan berkembang. Pembelajaran harus terkait dan peduli dengan aspek dari setiap kepribadian seperti bakat dan minat, kebebasan berpikir, perasaan, dan imajinasi yang diperlukan untuk menjadi pribadi yang lebih mandiri dan lebih bertanggung jawab. Tujuan dari pendidikan adalah untuk menemukan, membuka, dan mengangkat bakat dan potensi tersembunyi, seperti harta karun dalam diri setiap orang (Tim PGRI, 2014).

\section{METODOLOGI PENELITIAN}

Jenis penelitian yang digunakan dalam penulisan ini adalah penelitan kepustakaan (Library Research), yaitu serangkaian penelitian yang berkenaan dengan metode pengumpulan data pustaka, atau 
penelitian yang digali melalui beragam informasi kepustakaan seperti buku, ensiklopedi, jurnal ilmiah, koran, majalah, penelitian terdahulu dan dokumen (Nana Syaodih, 2009). Penelusuran pustaka ini dibatasi pada pembahasan tertentu dalam rangka untuk memperoleh data penelitian. fokus riset pustaka ini yaitu pada pengkajian dan analisis terhadap berbagai literatur yang memiliki hubungan dengan tema penelitian dan diakhiri dengan penarikan kesimpulan sebagai hasil temuan dalam penelitian.

\section{PEMBAHASAN}

\section{Pendidikan di Madrasah Berbasis Pendekatan Profetik}

Pendidikan profetik merupakan proses Transfer of Knowledge dan Transfer of Values yang bertujuan untuk mendekatkan diri kepada Tuhan Yang Maha Esa. Didalam Al-Qur'an surat Ali Imran ayat 110 Allah SWT menjelaskan tentang umat terbaik yang telah dilahirkan diatas muka bumi sebagai bagian terpenting dalam pendidikan profetik yakni menyeruh kepada yang ma'ruf (humanisasi), mencegah pada kemungkaran (liberasi), dan beriman kepada Allah (transendensi).

Dari penjelasan diatas menunjukan bahwa proses pembelajaran di madrasah berusaha untuk mengarahkan peserta didik tentang eksistensinya sebagai hamba Allah SWT yakni khalifah fil ardi yaitu manusia yang telah diberikan tugas dan tanggung jawab untuk menjaga alam semesta ini dengan cara merawat dan melastarikannya melalui pengamalan ajaran islam yaitu mengajak manusia untuk melakukan kebaikan, menyeruh manusia agar meninggalkan kemungkaran, dan beriman kepada Allah. Nilai-nilai kebaikan yang diajarkan kepada peserta didik tersebut diharapkan dapat memberikan kemaslahatan untuk semua.

\section{Transformasi Pengetahuan}

a. Humanisasi

Pada masa diutusnya Nabi Muhammad SAW, misi memanusiakan manusia merupakan tugas dan tanggung jawabnya sebagai seorang rasul. Manusia perlu diberikan sebuah pemahaman tentang hakikat manusia itu sendiri, yakni makhluk yang sangat unik dan memiliki berbagai macam potensi sebagai 
Anugrah dari sang maha pencipta yaitu Allah SWT. Potensi tersebut harus ditumbuh kembangkan melalui metode dan strategi yang tepat sebagaimana yang telah diajarkan oleh Nabi Muhammad SAW. Hal ini bisa kita lihat dari lahirnya sosok manusia-manusia terbaik hasil pengajaran, pendidikan dan bimbingan nabi Muhammad SAW seperti Abu Bakar Ashidiq, Umar bin Khatab, Usmana bin Affan, Ali bin Abi Thalib dan sahabat-sahabat nabi lainnya. Mereka adalah umat terbaik seperti yang dijelaskan dalam Al-Qur'an Surah Ali Imran Ayat 110 dan telah dijelaskan oleh penulis pada pembahasan seblumnya. Secara garis besar metode dan strategi yang digunakan oleh Nabi Muhammad SAW adalah mentransformasikan pengetahuan Agama melalui ayat-ayat Al-Qur'an dan hadits, memberikan contoh dan keteladanan yang baik. Misalnya, rajin bersedekah, memuliakan tamu, berbakti kepada kedua orang tua, memuliakan orang yang berilmu, sayang kepada istri, anak dan keluarga, adil, jujur, toleran, dan lain sebagainya.

Dalam konteks pendidikan formal, tugas dan tanggung jawab untuk memanusiakan manusia adalah guru. Dalam pendidikan profetik guru harus menjadikan nabi sebagai tolak ukur dan inspirasi serta motivasi dalam mendidik anak. Jadi, paradigma yang dibangun adalah anak yang baik lahir dari guru yang hebat. Guru harus bisa menjadi contoh dan teladan yang baik bagi peserta didiknya.

b. Liberasi

Lebarasi adalah pembebasan, yakni mebebaskan manusia dari belenggu ketidak adilan, ego kultural, hegemoni kaum kapitalis, pragmatis, individualis dan cinta dunia, serta masih banyak lagi. Melalui pendidikan profetik manusia diajarkan tentang pentingnya menghindari perbuatan-perbuatan maksiat, dosa dan kemungkaran. Manusia tidak boleh merasa terlena dengan kebaikan-kebaikan serta kenikmatan-kenimatan yang telah didapatkan selama ini. Sebab disisi lain manusia juga akan dihadapkan berbagai macam problematika kehidupan yang sangat 
kompleks. Dalam dunia pendidikan, kita sering dihadapkan dengan berbagai macam persoalan baik itu pada aspek kebijakan kurikulum, sekolah, guru, peserta didik dan lain-lain.

Membebaskan diri dari segala bentuk penyimpangan dan kemungkaran merupakan tanggung jawab bersama, baik itu pemerintah, sekolah, guru, dan orang tua. Melalui perbaikan kebijakan diharapkan pemerintah dapat merumuskan sebuah konsep pendidikan yang berkemajuan dan bisa menyelesaikan berbagai macam persoalan yang terjadi di institusi pendidikan salah satu contoh misalnya komersialisasi pendidikan, kapitalisasi pendidikan dan lain-lain.

Selain itu, guru adalah sosok yang sangat berpengaruh dalam menciptakan pendidikan yang baik di Indonesia. Disini, guru sangat menentukan keberhasilan peserta didik dalam belajar. Berdasarkan penerapan pendidikan di madrasah, tugas guru tidak hanya menyampaikan informasi kepada peserta didik, tetapi harus kreatif memberikan layanan dan kemudahan kepada seluruh peserta didik. Dengan demikian, kreativitas guru sangat diharapkan demi terwujudnya proses pembelajaran yang baik di sekolah. Tugas dan tanggung jawab untuk mendidik, membina dan mengajarkan peserta didik tidak sepenuhnya harus diserahkan kepada guru. Orang tua harus menjadi sosok yang sangat berpengaruh dan memberikan andil besar terhadap pertumbuhan dan perkembangan peserta didik.

Dari penjelasan diatas, maka tanggung jawab untuk membebaskan diri dari segala bentuk kemungkaran yang terjadi adalah tanggung jawab bersama sesuai dengan kapasitas, kemampuan dan kondisi yang terjadi. Pendidikan profetik tidaknya hanya dimaknai sebagai tanggung jawab individu yaitu Nabi Muhammad SAW. Supaya menjadi umat yang terbaik, maka kita harus menjadi bagian terpenting dalam menyelesaikan berbagai bentuk persoalan yang dihadapi. 
c. Transendensi

Transendensi merupakan kesadaran ketuhanan, vertikal manusia dalam memahami tentang Allah SWT (Iman). Iman adalah sebuah keyakinan, meyakini Allah SWT sebagai tuhan yang telah menciptakan manusia, menghidupkan, mematikan, memberi rezeki, dan lain sebagainya. Dengan menanamkan keyakinan tersebut, maka manusia akan berada pada derajat (level) kemuliaan di sisi Allah SWT.

Pendidikan Profetik pada point ini, mengajarkan kepada peserta didik tentang syarat diterimanya amal kebaikan yang dilakukan oleh umat manusia adalah iman. Bagi yang tidak beriman secara otomatis amal kebaikannya di tolak oleh Allah SWT. Selain itu, iman menjadi spirit atau energi positif yang diberikan oleh Allah SWT kepada hambanya yang aktif melakukan kebaikan-kebaikan. Peserta didik yang aktif melakukan kebaikan pada saat proses pembelajaran yang berlangsung di madrasah akan mendapatkan apresiasi, penghargaan serta kedudukan yang baik di sisi Allah SWT dan guru di madrasah.

2. Transformasi Nilai

Sebagaimana yang dilakukan oleh para nabi dan rasul utusan Allah SWT, maka nilai-nilai yang ditanamkan dalam pendidikan profetik adalah sebagai berikut

a. Tauhid

Dari 124.000 Nabi dan rasul utusan Allah SWT memiliki misi yang sama, yakni menyeru seluruh umat manusia untuk menyembah Allah SWT dan menjauhi segala bentuk penyembahan selain Allah (syirik). Perkara ini merupakan sesuatu yang sangat esensial dari ajaran yang dibawah oleh para nabi. Oleh karena itu, maka pendidikan profetik adalah pendidikan yang mengajarkan kepada peserta didik tentang Allah SWT baik pada aspek rububiyah, uluhiyah dan asma wasifat. Secara praktisnya materi tauhid dapat diterima oleh peserta didik pada mata pelajaran PAI dan Aqidah akhlak. 
b. Ibadah

Hakikat dari penciptaan manusia adalah untuk beribadah kepada Allah SWT sebagaimana telah dijelaskan dalam AlQur'an Surah Az-zariat ayat 56 yakni "Tidaklah ku ciptakan jin dan manusia melainkan hanya untuk beribadah kepada-ku". Untuk mewujudkan perintah ini maka Allah SWT memberikan kemudahan pada manusia dengan cara menjadikan nabi sebagai utusannya untuk dijadikan sebagai contoh dan panutan dalam beribadah. Ibadah yang diterima oleh Allah SWT adalah ibadah yang mengikhlaskan dirinya kepada Allah serta mengikuti tata cara yang dicontohkan oleh rasulullah saw seperti yang disabdakan dalam sebuah hadits "Shalatlah sebagaimana melihat aku shalat". Hal ini menunjukan bahwa pendidikan profetik adalah sebuah upaya secara maksimal untuk mempelajari dan memahami tentang hakikat dan tata cara beribadah yang baik dan benar manurut Al-Qur'an dan hadits. Selain itu, peserta didik juga diajarkan tentang kesadaran akan kewajibannya untuk beribadah hanya kepada Allah SWT.

c. Akhalkul Karimah

Manusia disamping sebagai makhluk individu, manusia juga merupakan makhluk sosial. Oleh karena itu, manusia tidak bisa hidup sendiri dan sangat bergantung kepada orang lain. Misi Nabi Muhammad SAW adalah menyebarkan rahmat untuk seluruh alam seperti yang difirmankan oleh Allah SWT dalam AlQur'an surah Al-Anbiya ayat 107 “dan kami tidak mengutus engkau Muhammad melainkan untuk menjadi rahmat bagi seluruh alam". Ayat ini mengindikasikan bahwa Nabi Muhammad diutus untuk mengajarkan kepada seluruh umat manusia tentang kasih saying, tolong menolong, saling mencintai, saling menghargai, dan lain sebagainya. Dengan demikian, maka pendidikan profetik adalah menanamkan kepada peserta didik tentang akhlak yang baik sebagai wujud manusia yang memilki budi perkerti luhur seperti yang diajarkan oleh nabi Muhammad SAW. 
Dari beberapa point penting yang telah dijelaskan diatas, tentu masih banyak nilai-nilai yang diajarkan oleh para nabi dan rasul (profetik) untuk dijadikan sebagai pelajaran serta dapat diajarakan kepada peserta didik di madrasah, sehingga melalui penerapannya dapat menghasilkan peserta didik yang menjunjung tinggi nilai-nilai ilahiah seperti yang telah dicontohkan oleh para nabi utusan Allah.

\section{Penerapan Pendidikan Profetik Untuk Mewujudkan Pilar Pendidikan Nasional di Madrasah}

Dalam rangka untuk mewujudkan pilar pendidikan nasional, maka proses penyelenggaraan pendidikan telah diatur oleh pemerintah Republik Indonesia yang secara jelas diuraikan dalam undang-undang Republik Indonesia No. 20 Tahun 2003 tentang sistem pendidikan nasional (Sisdiknas) pasal 4, bahwa (Amir Daien Indrakusuma, 1973):

1. Pendidikan diselenggarakan secara dekomratis dan berkeadilan serta tidak diskriminatif dengan menjunjung tinggi hak asasi manusia, nilai keagamaan, nilai kultural dan kemajuan bangsa.

2. Pendidikan diselenggarakan sebagai satu kesatuan yang sistemik dan kemajemukan bangsa.

3. Pendidikan diselenggarakan sebagai suatu proses pembudayaan dan pemberdayaan peserta didik yang berlangsung sepanjang hayat.

4. Pendidikan diselenggarakan dengan memberi keteladanan, membangun kemauan, dan mengembangkan kreatifitas peserta didik dalam prooses pembelajaran.

5. Pendidikan diselenggarakan dengan mengembangkan budaya membaca, menulis dan berhitung bagi segenap warga masyarakat.

6. Pendidikan diselenggarakan dengan memberdayakan semua komponen masyarakat melalui peran serta dalam penyelenggaraan dan pengendalian mutu layanan pendidikan.

Dalam konteks pembelajaran di abad 21, kegiatan pembelajaran dalam kurikulum 2013 di madrasah merupakan sebuah upaya untuk menginternalisasikan berbagai kompetensi yang harus dimiliki oleh peserta didik diantaranya adalah kompetensi pengetahuan, kompetensi sikap dan kompetensi keterampilan. Dalam pelaksanaannya pendidikan profetik dapat di 
aktualisasikan sebagai upaya untuk menanamkan berbagai kompetensi tersebut melalui materi-materi yang diajarkan oleh guru dalam berbagai mata pelajaran.

Pendidikan profetik adalah pendidikan yang selalu mengambil inspirasi dari ajaran nabi Muhammad saw. Prinsip dalam pendidikan profetik yaitu mengutamakan integrasi. Dalam memberikan suatu materi bidang tertentu juga dikaitkan dengan landasan yang ada di Al Qur'an dan As Sunnah, sehingga tujuan baik duniawi maupun akhirat dapat tercapai.

Nilai-nilai profetik dapat dipelajari dari sifat-sifat kenabian yang ada pada diri Rasulullah Saw. Berikut inilah sifat-sifat kenabian Rasulullah Saw. yang bisa menjadi inspirasi bagi peserta didik dalam pembentukan jati diri dalam pilar pendidikan nasional yang Islami:

1. Sidiq

Sidiq Secara sederhana sifat sidiq dapat diartikan sebagai kejujuran. Namun secara luas, sidiq juga merupakan sebuah integritas moral yang dimiliki oleh peserta didik. Kejujuran dinilai sebagai sebuah modal mendasar dalam membentuk integritas. Sifat jujur dapat dilatih dengan cara mendapatkan rizki yang halal. Rizki yang halal (didapatkan dengan cara jujur) adalah hal mendasar dari pembentukan integritas karena kejujuran adalah sifat yang hanya dapat dinilai oleh diri sendiri peserta didik.

2. Amanah

Amanah juga dapat diartikan sebagai sifat terpercaya. Sifat ini melatih peserta didik pada sifat bertanggung jawab dan dapat diandalkan. Karakter amanah akan dapat mengasah speserta didik dalam memilah dan memilih antara kepentingan pribadi dan kepentingan publik . Karakter ini dapat dilatih dengan cara mengemban tugas. Tugas yang berat akan semakin membentuk kualitas amanah yang baik pada diri seseorang peserta didik.

3. Tabligh

Tabligh dapat pula diartikan sebagai kemampuan komunikasi yang efektif. Dengan komunikasi yang efektif maka peserta didik dapat dengan mudah untuk menyampaikan visi dan misinya kepada peserta didik lainnya Komunikasi juga dipercaya sebagai kunci 
kesuksesan nomor satu. Karakter ini dapat dilatih dengan cara berani berbicara di depan publik dan berani menyampaikan pendapat.

4. Fathanah

Fatonah adalah karakter peserta didik dengan kualitas diri yang baik. Kualitas diri mencakup pada kecerdasan spiritual dan intelektual dan keterampilan Kecerdasan akan memberikan kepekaan peserta didik dalam mengambil keputusan dan memecahkan masalah. Sifat ini dapat dilatih dengan selalu menjadi pembelajar yang baik seumur hidup dengan berbagai cara yang didapat dari pengalaman diri sendiri, pengalaman orang lain, buku, dan berbagai sumber lainnya.

Dari empat nilai-nilai pendidikan profetik diatas, dapat dikembangkan melalui proses pelaksanaan pembelajaran di madrasah dengan memperhatikan proses secara keseluruhan, mulai dari proses belajar, pembentukan kompetensi, dan karakter peserta didik. Untuk mewujudkan pilar pendidikan nasional, maka pelaksanaan pembelajaran perlu memperhatikan beberapa prinsip sebagai berikut:

1. Berdasarkan kebutuhan belajar sebagai keinginan maupun kehendak yang dirasakan oleh peserta didik.

2. Berorientasi kepada tujuan kegiatan belajar. Prinsip ini mengandung arti bahwa pelaksanaan pembelajaran berorientasi kepada pencapaian tujuan yang telah ditetapkan.

3. Berpusat kepada peserta didik, yang menunjukan bahwa kegiatan belajar selalu bertolak dari kondisi riil kehidupan peserta didik.

4. Belajar berdasarkan pengalaman, bahwa kegiatan belajar harus dihubungkan dengan pengalaman peserta didik (Mulyasa, 2013).

Oleh karena itu, proses pembelajaran di madrasah guru bertindak sebagai fasilitator dengan memposisikan peserta didik sebagai subyek pembelajaran sehingga peserta didik lebih berperan aktif dalam kegiatan pembelajaran. Untuk mewujudkan pilar pendidikan nasional, pendidikan profetik tidak pahami sebagai model pendidikan tekstual normative, yaitu pola dan pendekatan pendidikan yang sifatnya doktrin teologis semata.

Berdasarkan penjelasan tersebut, Belajar menggunakan pendekatan pilar pendidikan, murid akan termotivasi dalam 
mengembangkan ilmu pengetahuan, pengalaman, dan keterampilan berpikir yang logis dan sistematis, sehingga suasana proses belajar mengajar menjadi kondusif, komunikatif dan tercipta hubungan harmonis antara guru dan peserta didik. Dan siswa akan belajar untuk mengetahui dan memunculkan pengetahuan yang ada pada siswa, belajar untuk berbuat dan memunculkan kreasi siswa yaitu berupa praktek, belajar untuk menjadi diri sendiri dan menjadikan siswa mempunyai bakat dan minat, dan belajar untuk hidup bersama membiasakan saling menghargai, terbuka serta memahami perbedaaan satu sama lain. Dengan demikian, maka pendidikan akan menjadikan manusia untuk dapat menguasai ilmu pengetahuan, memiliki keterampilan, menjadi dirinya sendiri sesuai dengan bakat dan kemampuannya, serta dapat hidup bersama dengan sesamanya.

\section{SIMPULAN}

Penerapan pendidikan profetik di madrasah bertujuan untuk mengarahkan peserta didik untuk berpartisipasi secara aktif dalam mengimplementasikan nilai-nilai perjuangan Rasulullah SAW yakni memanusiakan manusia (humanisasi), membebaskan manusia dari belenggu kemungkaran (liberasi), dan menjadi manusia beriman (transendensi) sebagaiman yang telah dijelaskan oleh Allah SWT dalam Al-Qur'an surah Ali Imran ayat 110.

Dalam konteks pendidikan secara formal pendidikan profetik dapat diterapkan untuk mewujudkan pilar pendidikan nasional melalui proses pembelajaran yang dilaksanakan di madrasah. Belajar menggunakan pendekatan pilar pendidikan, murid akan termotivasi dalam mengembangkan ilmu pengetahuan, pengalaman, dan keterampilan berpikir yang logis dan sistematis, sehingga suasana proses belajar mengajar menjadi kondusif, komunikatif dan tercipta hubungan harmonis antara guru dan peserta didik.

\section{DAFTAR PUSTAKA}

Abu Ahmadi. 2004. Widodo Supriyono, Psikologi Belajar, Jakarta, Rineka Cipta.

Ali Shari'ati. 1996. Humanisme: Antara Islam dan Mazhab Barat, terj. Husein Anis al- Habshi, Bandung, Pustaka Indah.

Amir Daien Indrakusuma. 1973. Pengantar Ilmu Pendidikan, Malang, Fakultas Ilmu Pendidikan IKIP. 
Azyumardi Azra. 1999. Pendidikan Islam: Tradisi dan Modernisasi Menuju Milenium Baru, Jakarta: Logos Wacana Ilmu.

Azyumardi Azra. 2006. "Faith, Values, and Integrity in Public Life", makalah disampaikan pada World Ethis Forum: Leadership, Ethics, and Integrity ini Public Life, Oxford, International Institute for Public Ethics (IPPE) dan The World Bank.

Departemen Agama RI. 2009. Al-Qur'an dan Terjemahannya, Bandung, Sianr Baru Algesindo.

Komarudin Hidayat. 2014. "Pendidikan dan Martabat Bangsa", Tulisan Prolog Dalam Buku Pendidikan Untuk Tranformasi Bangsa, Jakarta, Dewan Pakar Pengurus Besar PGRI.

Kuntowijoyo. 1991. Paradigma Islam: Interpretasi Untuk Aksi, Bandung, Mizan.

Kuntowijoyo. 2001. Muslim Tanpa Masjid, Bandung, Mizan.

Kuntowijoyo. 2007. Islam Sebagai Ilmu: Epistemologi, Metodologi, dan Etika, Yogyakarta, Tiara Wacana.

Marwan Saridjo. 1996. Bunga Rampai Pendidikan Agama Islam, Jakarta, Amisso.

Mastuhu. 2001. Menata Ulang Pemikiran Sistem Pendidikan Nasional Abad 21, Yogyakarta, Safiria Insania Press.

M. Fahmi. 2005. Islam Transendental: Menelusuri Jejak-jejak Pemikiran Islam Kuntowijoyo, Yogyakarta, Pilar Religia.

Muhammad Basyam Rusydi Az-Zain. 2007. Sekolah Para Nabi 1 \& 2., Yogyakarta, Pustaka Marwa.

Mulyasa. 2013. Pengembangan dan Implementasi Kurikulum 2013, Bandung, Remaja Rosdakarya.

Nana Syaodih. 2009. Metode Penelitian Pendidikan, Bandung, PT Remaja Rosdakarya

Sudarwan Danim. 2006. Agenda Pembaharuan Sistem Pendidikan, Yogyakarta, Pustaka Pelajar.

Syaifullah Godi Ismail. 2012. "Implementasi Pendidikan Profetik Dalam Pembelajaran Pendidikan Agama Islam". Dalam Jurnal Mudarrisa: Kajian Pendidikan Islam Vol. 5 No. 2 Desember 2012 SMPN 4 Salatiga.

Tim PGRI. 2014. Pendidikan Untuk Transformasi Bangsa: Arah Baru Pendidikan Untuk Perubahan Mental Bangsa, Jakarta, PT Gramedia. 